\title{
El lado afro de la Puebla de los Ángeles*
}

* Rodríguez Ortiz, Guillermo Alberto, El lado afro de la Puebla de los Ángeles. Un acercamiento al estudio sobre la presencia africana,1595-1710, BUAP - Piso 15 Editores, 2015.

Tla-Melaua, revista de Ciencias Sociales. Facultad de Derecho y Ciencias Sociales. Benemérita Universidad Autónoma de Puebla, México / issn: 1870-6916 / Nueva Época, año 10, núm. 41, octubre 2016/marzo 2017, pp. 242-245. 
A ideia de uma "presença negra" no México tem sido alvo de constantes investigações e indagações de pesquisadores na atualidade. Inicialmente pensada enquanto o centro, um dos "corações" do vasto Império espanhol no decorrer do processo de conquista da América, os trabalhos sobre o México colonial versavam sobretudo acerca do relacionamento entre europeus e indígenas, pelos quais se vislumbrava em certos momentos a passividade do elemento indígena - destacadamente os astecas e os maias - e, a partir dos anos 1970, uma produção historiográfica voltada para a perspectiva de um olhar aos "vencidos" e sua história, seus conflitos e negociações dentro do novo mundo que se configurava com a chegada do elemento europeu.

Nesse sentido, muito do que se produziu sobre o México no período colonial retratou o papel de espanhóis e indígenas no decorrer deste processo ao traçar questões que envolvam as ações, avanços e retrocessos destes dois agentes na formação da sociedade mexicana. A mestiçagem indígena foi pensada como o marco fundador destes povos, ressignificado em diversos momentos para assegurar a coesão dos grupos sociais. Contudo, a presença africana e suas contribuições ao país foram pouco exploradas nesse ponto, aspecto este bastante analisado para regiões como Cuba, Nova Granada e a América do Norte.

O trabalho desenvolvido pelo historiador mexicano Guillermo Rodríguez se propõe a contribuir para discutir a presença de um "lado afro" ao longo do processo de desenvolvimento da sociedade colonial da Nova Espanha. Nesta direção, o autor se debruça sobre a cidade de Puebla de los Ángeles dentre os séculos XVI e XVIII. Este "lado afro" se apresenta sob certo ar de dúvidas, surpresas e desconfiança. A negritude seria, na visão do autor, uma terceira "raiz cultural" que envolve o povo mexicano.

Assim como Rodríguez, outros autores pensaram o papel dos negros na região. O próprio processo de conquista do Novo Mundo contou com a presença de negros entre os conquistadores mexicanos. A malfadada expedição de Pánfilo de Narváez e Alvar Nuñez Cabeza de Vaca teve como um de seus membros um negro africano chamado Estevam. A título de exemplo, Ben Vinson III foi um dos principais autores que abordaram o uso de negros africanos para constituir as forças de defesa de regiões estratégias ao Império, tais como a Nova Espanha e as ilhas do Caribe hispânico. A escravidão negra

\footnotetext{
* Doutoranda em História Social pela Universidade Federal Fluminense (UFF). Professora de História na rede estadual de ensino pela Secretaria de Estado e Educação do Rio de Janeiro (Seeduc-RJ). (hfacruche@gmail.com)
} 
no Império espanhol fez parte do processo de conquista, sendo assim um de seus motores. Então, por que não contar a história deste "lado afro" e sua contribuição para a sociedade? Arrisco dizer que este é um dos méritos do livro.

Ao partir de um olhar que canaliza o universo geral para direcionar às particularidades de um dado fenômeno, o autor conseguiu traçar um panorama da presença negra na colônia da Nova Espanha e, por conseguinte, o papel da legislação e do trato negreiro para as Américas. A importância de compreender o comércio de pessoas negras nos permite indagar sobre temas corriqueiros, tais como o peso desta atividade para o desenvolvimento da economia colonial e os graus de resistência, acomodação e negociação existentes entre, por um lado, os vassalos da monarquia e, por outro, as populações indígenas e africanas; onde a promoção de uma série de diferenciações - pautadas sobretudo pela cor da pele - levou a construção de categorias de análise e classificações expressas em livros, discursos e obras de arte do período.

Rodríguez prossegue sua análise colocando em evidência elementos da produção historiográfica sobre o assunto de forma dialógica com as fontes encontradas no decorrer do processo de pesquisa. $\mathrm{O}$ mesmo leva em consideração, especialmente no terceiro capítulo, as conexões existentes entre o comércio negreiro para o continente americano e, no particular, para o mexicano. Um fenômeno semelhante que também implicava em questões semelhantes tanto no universo da Nova Espanha quanto de outros espaços sob domínio hispânico. Na medida em que a leitura segue, percebemos seu apreço pelos termos quantitativos; os quais também são importantes a construção de uma história demográfica e das populações.

O quinto capítulo, "Africanos y los afrodescendientes en la Puebla de los Ángeles, 1595-1710", reflete a preocupação do autor em pensar uma História Regional relacionada com a História Social. Sendo a "segunda ciudad novohispana" no século XVII, Rodríguez foi singular tanto na análise da presença africana naquele ambiente, as interações com os conquistadores espanhóis quanto o registro documental de sua presença cotidiana através de pesquisa minuciosa no Archivo General Municipal de Puebla, no Archivo General de Notarias del Estado de Puebla e, por fim, nos Archivos parroquiales.

Pensar os espaços onde se preservam as fontes de nosso trabalho, onde de certa forma as mesmas sobrevivem ao tempo, foi uma característica singular do trabalho de Guillermo Rodríguez, para o qual cabe a nós, pesquisadores e estudantes, indagarmos sobre o estado de nossas instituições e o que elas abrigam. É válido refletir sobre a importância de um arquivo para a construção de uma história social, demográfica e dos feitos cotidianos que se comprometa também a tratar das sobrevivências, das rupturas e permanências das pessoas que ali viviam e seus hábitos, costumes e modos variados de vida. Em outras palavras, observar o espaço dos arquivos não apenas enquanto guardiões 
do passado, mas também como construtores de memórias tanto do passado quanto do tempo presente. Para o autor, os arquivos são espaços privilegiados para refletir sobre o "lado afro" e o estudo da terceira raiz cultural no México.

Por fim, o trabalho de Guillermo Rodríguez nos revela singularidades que não tratam apenas do passado, mas também de questões pertinentes ao presente. Antes de pensar os vários impactos do "infame comércio", da travessia África-América, das formas de resistir e negociar em meio a uma sociedade constituída por inúmeras hierarquias, o trabalho de pesquisa empreendido pelo autor nos permite ver o esforço em mostrar a presença negra e demarcar um pouco de sua história presente através dos indícios do passado. Não é à toa que no Prólogo os termos surpresa, desconfiança e dúvida aparecem como características inerentes ao trabalho desenvolvido.

A concepção de que pessoas de cor negra fizeram e fazem parte de nossa história foram silenciados por séculos de exploração, desigualdades e violência em vários espaços do continente americano; onde a própria existência de escravos foi questionada durante anos em alguns lugares, tais como Buenos Aires, considerada uma parte da Europa nos trópicos americanos. Para tanto, este livro nos fornece subsídios importantes para pensar o "lado afro" na sociedade mexicana, mas também essa presença no restante da América, ou seja, o nosso próprio "lado afro". 